\title{
Activin receptor-like kinase 7 induces apoptosis of pancreatic beta cells and beta cell lines
}

Received: 6 July 2005 / Accepted: 6 October 2005 / Published online: 27 January 2006

(C) Springer-Verlag 2006

\begin{abstract}
Aims/hypothesis: Activin receptor-like kinase 7 (ALK7), a member of the type I receptor serine/threonine kinases of the TGF- $\beta$ superfamily, was recently reported to regulate cell proliferation and apoptosis. We hypothesised that ALK7 may play a role in modulating pancreatic beta cell proliferation and/or apoptosis. Methods: We detected ALK7 expression in beta cells using RT-PCR, immunostaining and western blotting. Constitutively active, dominant negative or wild-type ALK7 was introduced into beta cells using adenoviral delivery. Proliferation was assessed using ${ }^{3} \mathrm{H}$-thymidine incorporation and apoptosis was quantified using terminal deoxynucleotidyl transferase biotin-dUTP nick end labelling detection, DNA degradation analysis and caspase-3 assays. Results: Induction of constitutively active ALK7 in beta cells resulted in growth inhibition and enhanced apoptosis; no effect was seen with INS-1 cells expressing wild-type or dominant negative ALK7. Elevated glucose concentrations and fatty acid (palmitate) markedly increased expression levels of ALK7 transcripts and proteins in INS-1 and rat islets and increased beta cell apoptosis. Activation of ALK7 increased Smad2 phosphorylation, reduced protein kinase B (Akt) kinase
\end{abstract}

\footnotetext{
N. Zhang · M. Kumar · W. Ju · T. Yoon ·

E. Xu $\cdot$ Q. Wang $(\square)$

Division of Endocrinology and Metabolism,

St Michael's Hospital,

30 Bond Street, Room 7005,

M5B 1W8 Toronto, ON, Canada

e-mail: qinghua.wang@utoronto.ca

Tel.: +1-416-8646060

Fax: +1-416-8646043

N. Zhang $\cdot$ M. Kumar $\cdot$ W. Ju $\cdot$ E. Xu

X. Huang $\cdot$ H. Gaisano $\cdot$ Q. Wang

Departments of Physiology and Medicine,

University of Toronto,

Toronto, ON, Canada

G. $\mathrm{Xu} \cdot \mathrm{C}$. Peng

Department of Biology,

York University Toronto,

Toronto, ON, Canada
}

N. Zhang and M. Kumar contributed equally to this study. activity and was associated with increased levels of the bioactive forms of caspase-3, whereas co-expression of constitutively active ALK7 with dominant negative Smad2 or constitutively active Akt significantly diminished ALK7induced growth inhibition and apoptosis in INS-1 cells. Although overexpression of constitutively active Akt significantly reduced ALK7-induced growth inhibition and ALK7-enhanced beta cell apoptosis, ALK7-stimulated Smad2 phosphorylation was not affected. Conclusions/ interpretation: These results suggest that the pancreatic beta cell apoptosis induced by ALK7 activation occurs via the activation of two distinct downstream pathways: the suppression of Akt activation and the activation of the Smad2-caspase-3 cascade.

Keywords Activin receptor-like kinase $7 \cdot$ Apoptosis · Beta cell · Caspase-3 - Growth · Proliferation · Protein kinase B · Smad

Abbreviations ActRI: activin receptor type I - ActRII: activin receptor type II $\cdot$ Ad: adenovirus - Akt: protein kinase B - ALK7: activin receptor-like kinase 7 - Bax: BCL2-associated X protein - CA: constitutively active . DN: dominant negative $\cdot$ ERK: extracellular signalregulated protein kinase - GFP: enhanced green fluorescent protein - JNK: Jun $N$-terminal kinase - MAPK: mitogenactivated protein kinase $\cdot$ MOI: multiplicity of infection TUNEL: terminal deoxynucleotidyl transferase biotindUTP nick end labelling $\cdot$ Wt: wild-type $\cdot$ XIAP: $\mathrm{X}$-chromosome linked inhibitor of apoptosis

\section{Introduction}

The TGF- $\beta$ superfamily comprises a wide range of factors including TGF- $\beta$, activins, bone morphogenetic proteins, and Nodal and related proteins [1-3]. Members of the TGF- $\beta$ superfamily regulate diverse cellular and physiological functions including early developmental processes, cell growth, apoptosis, neuronal and endocrine cell communication, and immune responses $[4,5]$. Two types of 
transmembrane serine/threonine kinase receptor (type I and type II) are responsible for mediating the biological functions of the TGF- $\beta$ superfamily [3]. Type II receptors, upon ligand binding, recruit and phosphorylate type I receptors at an intracellular segment consisting of glycine and serine residues (GS box) [1]. The two receptors form a functional heteromeric receptor complex and initiate intracellular signalling cascades by phosphorylating the Smad proteins $[6,7]$. The phosphorylated Smad protein complexes are then translocated into the nucleus to modulate target gene transcription (Fig. 1) [3].

In addition to the functional domains identified in Smad proteins, i.e. the DNA binding domain (MH1) and the transcription factor interaction domain (MH2), a number of phosphorylation sites have been identified, including target sites for mitogen-activated protein kinase (MAPK), protein kinase C, calcium-mediated kinase II and Jun $N$-terminal kinase (JNK) [1], suggesting that the involvement of other protein kinase families may contribute to a greater versatility of Smad signalling [1, 8, 9]. Furthermore, recent studies have also suggested that activation of the heteromeric receptor complexes at the cell surface can initiate Smad-independent pathways via signalling molecules such as phosphoinositide-3-kinase [10,11], extracellular signalregulated protein kinase (ERK)/MAPK, JNK and p38MAPK $[1,12]$.

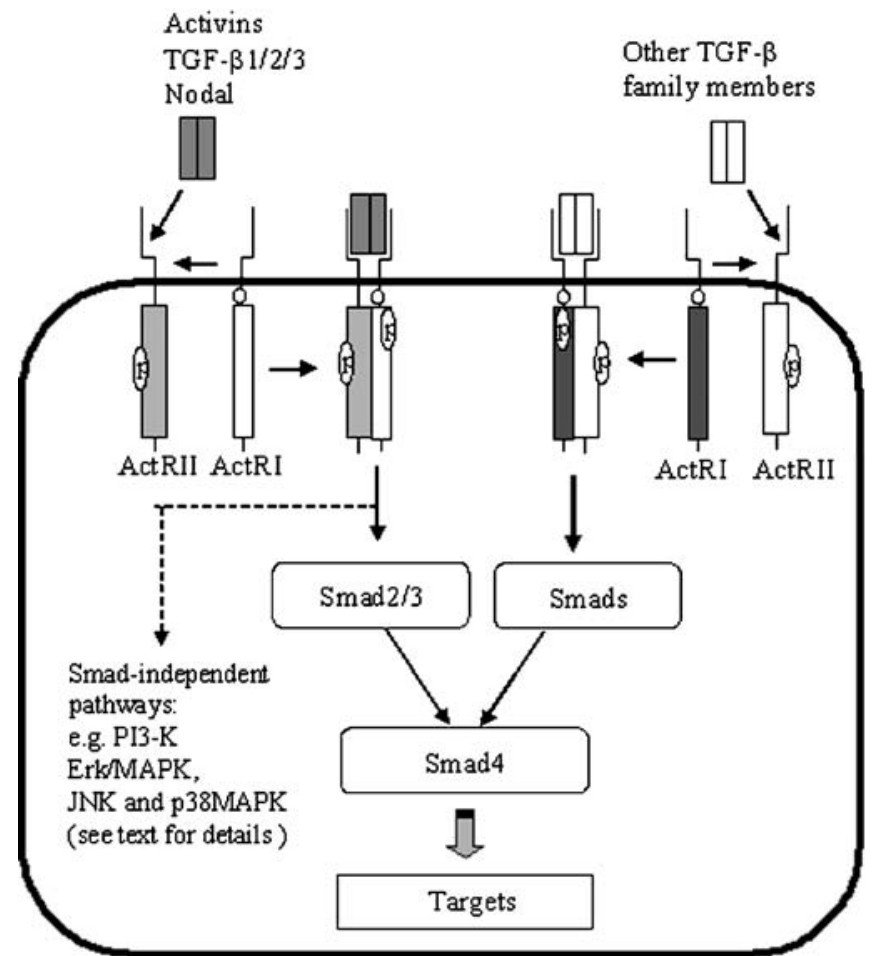

Fig. 1 Signalling pathways for the TGF- $\beta$ superfamily. TGF- $\beta$ ligands/activins bind directly to ActRII, and this complex associates with ActRI. As a result, ActRI is phosphorylated (p) by the kinase activity of ActRII. Activated receptor kinase ActRI in turn phosphorylates Smad proteins, including Smad2 and Smad3. Note that receptor activation can also activate Smad-independent pathways. In addition, a number of phosphorylation sites have been identified on the Smad proteins, including target sites for ERK/ MAPK, protein kinase C, CamKII and JNK
To date, seven type I receptors, referred to as activin receptor-like kinases (ALK1-7), and five type II receptors have been cloned from mammals [13]. ALK7 was initially cloned from rat brain as an orphan receptor and ALK7 mRNA has been detected in the embryonic brain, adult central nervous system, prostate and adipose tissue, and fetal and adult pancreas [14]. In humans, ALK7 has been mapped to the gene locus 2q24.1-q3 and its mRNA has been found in the brain, pancreas, colon, ovary and placenta during all stages of pregnancy $[15,16]$. Upon heterodimerisation with activin receptor type II (ActRII) B, ALK7 confers responsiveness to Nodal and its related proteins [17]. ALK7 can form a complex with ActRIIA to mediate signalling by activin $B$ and activin AB [18]. The kinase domain of ALK7 shares a high degree of similarity with that of ALK4 (activin receptor type I [ActRI] B) and ALK5 (TGF- $\beta$ receptor type I) [19]. Like ALK4 and ALK5, ALK7 also uses the same regulated Smad (RSmad) proteins (Smad2 and Smad3) to convey signals [15]. Functional studies using constitutively active ALK7 (CAALK7) have shown that activation of ALK7 signalling arrests proliferation and morphological differentiation in neuronal cells [9], and inhibits proliferation and induced apoptosis in human epithelial ovarian cancer cells [20], human trophoblast cells [21] and hepatoma cells [22].

The loss of islet beta cells through apoptosis (programmed cell death) is a cause of type 1 and type 2 diabetes (for review see [23]). Members of the TGF- $\beta$ superfamily, particularly activins, have been implicated in regulating islet beta cell apoptosis as well as proliferation, differentiation and other functions [24-26]. Transgenic fetal and postnatal mice expressing a dominant negative form of activin receptor or a constitutively active form of activin receptor had lower survival rates, smaller islet mass and lower pancreatic insulin content associated with impaired glucose tolerance [27]. In addition, ALK7 and ActRIIA mediate the effects of activin $\mathrm{B}$ and activin $\mathrm{AB}$ on insulin secretion by pancreatic beta cells [28]. However, the precise downstream events activated by ALK7 in the islet beta cells are unknown. We attempted to elucidate the specific cellular events by which ALK7 regulates beta cell proliferation and apoptosis. Using adenoviral-based gene delivery techniques, we found that overexpression of the constitutively active form of ALK7 [20,21] reduced beta cell proliferation and increased apoptosis. Our data suggest that the suppression of cell growth and the induction of cell death by ALK7 occur via suppression of the cell survival mechanism. This involves reduction of protein kinase B (Akt) activity and, simultaneously, activation of Smadassociated apoptotic pathways.

\section{Materials and methods}

Plasmids, cells and adenovirus preparation

The construct pcDNA3 CA-Akt was a kind gift from J. R. Woodgett (University of Toronto). Dominant negative (DN) Smad2 was kindly provided by R. Derynck 
(University of California, San Francisco). ALK7 cDNAs, including wild-type (Wt), constitutively active (CA; the threonine-194 was replaced with aspartic acid) and DN (the lysine-222 was replaced with arginine) forms of ALK7, were made as reported previously [20, 21]. MIN6 and INS1 cells were a kind gift from $\mathrm{M}$. Wheeler (University of Toronto); InRIG9 cells [29] were provided by D. Drucker (University of Toronto). The culture medium for MIN6 and INS-1 cells was RPMI 1640 (Invitrogen, Carlsbad, CA, USA) containing $10 \mathrm{mmol} / 1$ HEPES, $10 \%$ fetal bovine serum, $100 \mathrm{U} / \mathrm{ml}$ penicillin $\mathrm{G}, 100 \mu \mathrm{g} / \mathrm{ml}$ streptomycin, $1 \mathrm{~mol} / 1$ sodium pyruvate, $50 \mu \mathrm{M}$ 2-mercaptoethanol and $10 \mathrm{~mol} / \mathrm{l} \mathrm{NaOH}$; DMEM was used for INR1G9 cells [29] and acinar AR42J cells [30]. Cells were grown in monolayer cultures and were maintained at $37^{\circ} \mathrm{C}$ in a humidified atmosphere with $5 \% \mathrm{CO}_{2}$. In studies involving serum starvation, serum was replaced with $0.1 \% \mathrm{BSA}$ in the medium.

Adenoviral ALK7 constructs were made using the AdEasy system (Cloncancer.org) [31]. Briefly, different forms of ALK7 plasmids were first subcloned into a shuttle vector (pAdTrack-CMV). After linearising by digestion with PmeI, the plasmids were cotransformed into E. coli BJ5183 cells with an adenoviral backbone plasmid (pAdEasy-1). Recombinants were selected for kanamycin resistance and were further confirmed by restriction enzyme analysis with $B g l \mathrm{II}$. After linearisation with PacI, the recombinant plasmids were transfected into adenovirus packaging HEK293 cells. The viruses were purified as described previously [31].

\section{Insulin secretion}

Insulin concentrations were measured using an insulin RIA kit (Linco Research, St Louis, MO, USA) as previously described [32]. INS-1 cells grown in 24-well plates to $85-$ $90 \%$ confluency were rinsed twice and incubated with Krebs-Ringer bicarbonate buffer (KRB) containing $115 \mathrm{~mol} / \mathrm{l} \mathrm{NaCl}, 5 \mathrm{~mol} / \mathrm{l} \mathrm{KCl}, 24 \mathrm{~mol} / \mathrm{l} \mathrm{NaHCO}_{3}$, $2.5 \mathrm{~mol} / 1 \mathrm{CaCl}_{2}, 1 \mathrm{~mol} / 1 \mathrm{MgCl}_{2}, 10 \mathrm{~mol} / 1$ HEPES and $0.1 \%$ BSA for $60 \mathrm{~min}$. Cells were incubated in KRB in the presence of various concentrations of glucose (dextrose; Merck, Darmstadt, Germany) as indicated. After $30 \mathrm{~min}$ of incubation, the media were collected and insulin levels measured by RIA using a rat insulin RIA kit (Linco Research, St Charles, MO, USA) according to the manufacturer's instructions. The insulin secretion was normalised to the cellular protein content. Protein was determined using the Bio-Rad protein assay kit (Bio-Rad Laboratories, Hercules, CA, USA).

\section{Adenoviral infection and transient transfections}

INS- 1 cells were incubated with adenovirus for $2 \mathrm{~h}$, rinsed, and placed in complete medium to recover for an additional $22 \mathrm{~h}$. For some experiments, $6 \mathrm{~h}$ after adenoviral infection of the INS-1 cells, cells were washed and transfected
( $2.5 \mu \mathrm{g}$ per well on a six-well plate) with control pcDNA3, DN-Smad2, CA-Akt or DN-ALK7 plasmids using Lipofectamine 2000 Plus (Invitrogen, Mississauga, ON, Canada) for an additional $16 \mathrm{~h}$ according to the manufacturer's instructions. Pilot studies were done to evaluate the transfection efficiency. Lipofectamine yielded an $80-85 \%$ transfection rate in the beta cells, as evaluated by expression of green fluorescent protein (GFP).

\section{Islet isolation}

Rat islets were isolated from the pancreas of male SpragueDawley rats (weight 150-200 g), obtained from Charles River Canada (Montreal, QC, Canada), using collagenase digestion and dispersion into single islet cells as described previously [33]. Single islet cells were seeded onto glass coverslips coated with poly-D-lysine (Sigma Chemical, St Louis, MO, USA) and allowed to adhere prior to use in immunofluorescence experiments. For some experiments, islets were placed into $10 \mathrm{~cm}$ tissue culture plates and were hand-picked for use in mRNA or protein extraction studies.

\section{RT-PCR}

Total RNA was extracted using Trizol (Invitrogen) following the manufacturer's instructions. One hundred nanograms of template was used to analyse the expression of ALK7, using the One-step RT-PCR kit (Qiagen, Valencia, CA, USA) in a final volume of $25 \mu$ l containing Qiagen RT-PCR buffer and $2 \mu$ lof Qiagen One-step RTPCR enzyme mix, $400 \mu \mathrm{mol} / 1$ of each dNTP and $0.48 \mu \mathrm{mol} / 1$ of forward and reverse primers specific to ALK7. The sequences of the primer pairs were as follows: (1) ALK7: forward, 5'-CCTCTGGATCTGGCTCTGGTC TAC-3'; reverse, 5'-GTCCGCTATGGCACAAGTTTCA C-3'. 2) BCL2-associated X protein (BAX): forward, 5'AGACAGGGGCCCTTTTGCTTC-3'; reverse, 5'-TGCA GCTCCATGTTACTGTCC-3'. RT-PCR was performed at $50^{\circ} \mathrm{C}$ for $30 \mathrm{~min}$, and $95^{\circ} \mathrm{C}$ for $15 \mathrm{~min}$ followed by 35 cycles of PCR at $94^{\circ} \mathrm{C}$ for $30 \mathrm{~s}, 60^{\circ} \mathrm{C}$ for $30 \mathrm{~s}$ and $72^{\circ} \mathrm{C}$ for $1 \mathrm{~min}$, and culminating in extension for $15 \mathrm{~min}$ at $72^{\circ} \mathrm{C}$. Products were separated on an agarose gel and visualised using ethidium bromide.

\section{Western blot analysis}

Cells were lysed in RIPA (radio-immunoprecipitation assay) lysis buffer containing the protease inhibitors phenylmethylsulphonylfluoride (PMSF) (1 mol/l) and EDTA (1 mol/l); $\mathrm{Na}_{3} \mathrm{VO}_{4}(1 \mathrm{~mol} / \mathrm{l})$; and $\mathrm{NaF}(1 \mathrm{~mol} / \mathrm{l})$. Rat brain or pancreatic tissue (50-100 mg total wet weight) was minced and homogenised in RIPA lysis buffer. About $20 \mu \mathrm{g}$ of protein was resolved by SDS-PAGE and transferred to nitrocellulose membranes using semi-dry transfer (Bio-Rad Laboratories). The membranes were probed with primary poly- or monoclonal anti-ALK7 
antibodies (1:1,000), anti-phospho-Smad2 (1:250; R and D Systems, Minneapolis, MN, USA), anti-Akt and antiphospho-Akt (1:1,000), anti-cleaved caspase-3 (1:1,000; Cell Signaling, Mississauga, ON, Canada) or anti-beta-actin (1:2,000; Sigma Chemical), visualised with horseradish peroxidase-conjugated secondary antibodies using electrochemiluminescence (ECL) Plus detection (Amersham, Mississauga, ON, Canada), and analysed by densitometry.

Immunocytochemistry

Islet cells or cell lines were fixed using $4 \%$ paraformaldehyde and permeabilised using $0.1 \%$ Triton X-100 in PBS, and then blocked (3\% bovine serum albumin in PBS, $1 \mathrm{~h}$ ) prior to overnight incubation with the appropriate antibodies: mouse or goat anti-ALK7 $\operatorname{IgG}(1: 500 ; \mathrm{R}$ and D Systems), guinea-pig anti-insulin $(1: 1,000)$ or rabbit antiglucagon (1:1,000; DakoCytomation, Mississauga, ON, Canada). The corresponding fluorescein isothiocyanate (FITC)- or Cy3-conjugated secondary antibodies were used prior to visualisation using confocal microscopy (Zeiss LSM 510).

Proliferation and cell death assays

Cell growth and death were determined by cell counting using a light microscope and Trypan Blue exclusion, which discriminates dead cells (stained) from living cells (non-stained) [34]. Cell proliferation was measured in non-infected cells or cells infected with various adenoviral ALK7 (Ad-ALK7) or Ad-GFP (control) vectors using ${ }^{3} \mathrm{H}$-thymidine (Perkin-Elmer, Boston, MA, USA) incorporation, by incubating the cells with the culture medium containing ${ }^{3} \mathrm{H}$-methylthymidine for $4 \mathrm{~h}$, as described previously [35].

Twenty-four hours after viral infection, INS-1 cell apoptosis was determined by terminal deoxynucleotidyl transferase biotin-dUTP nick end labelling (TUNEL) using the In Situ Cell Death Detection Kit, TMR red (Roche Diagnostics, Mannheim, Germany) according to the manufacturer's instructions. For DNA degradation analysis, floating and adherent cells were combined and centrifuged at $400 \mathrm{~g}$ for $5 \mathrm{~min}$ and rinsed twice with PBS. The pellet was resuspended in $0.2 \mathrm{ml}$ lysis buffer (100 mol/l NaCl, $10 \mathrm{~mol} / \mathrm{l}$ Tris [pH 8.0], 1 mol/l EDTA, $0.5 \%$ SDS, $0.2 \mathrm{mg} / \mathrm{ml}$ proteinase $\mathrm{K}, 200 \mu \mathrm{g} / \mathrm{ml}$ RNAse A) and incubated at $37^{\circ} \mathrm{C}$ for $2 \mathrm{~h}$. DNA was then extracted twice with phenol/chloroform and then with chloroform alone. The DNA was then precipitated and washed in $70 \%$ ethanol prior to resuspension in $1 \mathrm{~mol} / \mathrm{l} \mathrm{EDTA}, 10 \mathrm{~mol} / 1$ Tris- $\mathrm{HCl}(\mathrm{pH} \mathrm{8.0)}$ to a final concentration of $20 \mu \mathrm{g} / \mathrm{ml}$. The DNA fragments were resolved using a $1.5 \%$ agarose gel. Naive INS- 1 cells treated with $\mathrm{H}_{2} \mathrm{O}_{2}(50 \mu \mathrm{mol} / 1,24 \mathrm{~h})$ were used as a positive control.
Detection of active form of caspase-3

The INS-1 cells infected with various adenoviral vectors and/or transfected with various vectors were permeabilised and probed using anti-active caspase- 3 antibody $(1: 1,000$; Cell Signaling) as described above.

\section{Statistical analysis}

All data are presented as mean \pm SEM. Statistical analysis was done by with Student's $t$-test or ANOVA using $n-1$ custom hypotheses tests as appropriate. Significance was assumed at a $p$ value of less than 0.05 .

\section{Results}

Expression of ALK7 in pancreatic islet-cells and INS-1 cells

RT-PCR analysis of ALK7 expression demonstrated that the rat islet and insulin-secreting beta cell lines INS-1 and MIN6 (not shown) expressed the ALK7 transcript (Fig. 2a). ALK7 mRNA was also detected in the glucagon-secreting INR1G9 cells but not in the clonal acinar AR42J cells or in the control (Fig. 2a). Expression of ALK7 proteins was determined by western blot analysis. A $55 \mathrm{kDa}$ band was readily detected in the beta cell lines (INS-1 and MIN6), alpha-cell line (INR1G9), rat pancreas, isolated rat islets and rat brain tissue (Fig. 2b), together with a $44 \mathrm{kDa}$ band in the rat pancreas and rat brain tissue

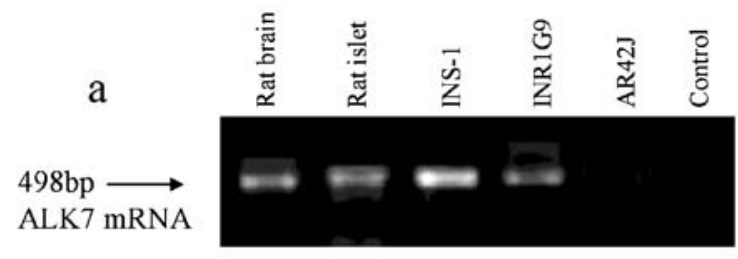

b

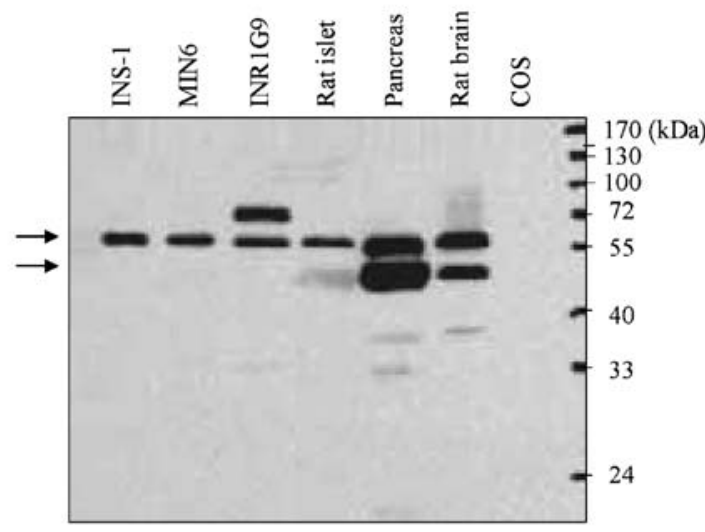

Fig. 2 Expression of ALK7 mRNA transcripts in islet cells. a ALK7 mRNA was examined by RT-PCR from various tissues and cell lines. b Proteins from INS-1, MIN6, INR1G9 cells, isolated rat islets, rat pancreas, rat brain and COS cells were examined for ALK7 expression by western blot analysis. The data shown are typical of three to five similar experiments 

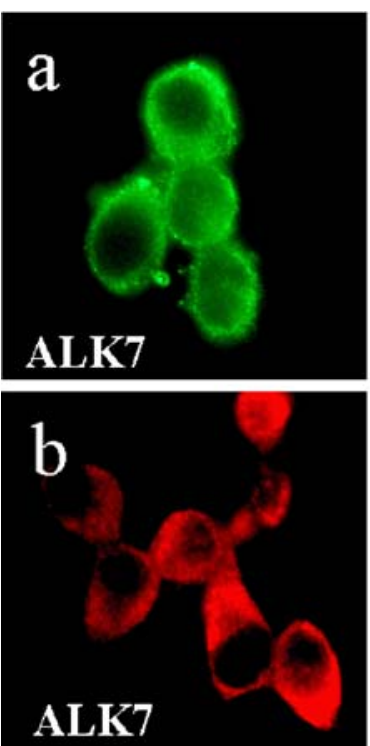
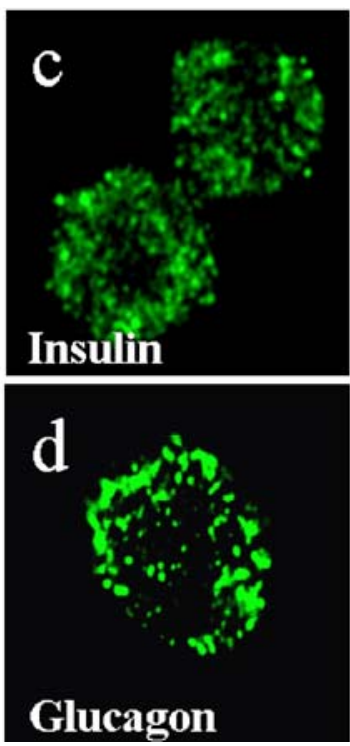
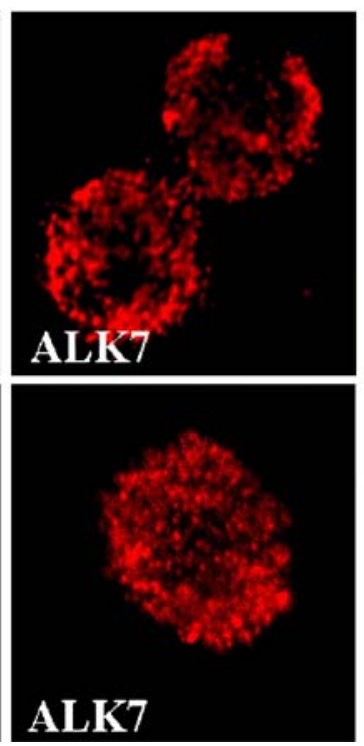
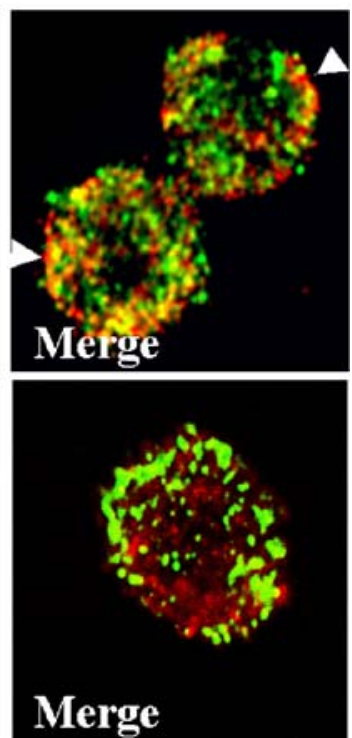

Fig. 3 Cellular and pancreatic localisation of ALK7. Confocal images of INS-1 cells using goat anti-ALK7 (a) or mouse antiALK7 (b), and visualised using either FITC (green) or Cy3 (red). c Two dispersed single rat islet cells, dual-stained for insulin (green) and ALK7 (red), and visualised by confocal microscopy

with the merged image as indicated. d Single islet cell, dualstained and visualised as above, with the exception that green indicates glucagons. The data shown are typical of three similar experiments

Fig. 4 The effect of ALK7 on INS-1 cell growth, death and proliferation. a Glucose stimulated insulin secretion from INS-1 cells in a concentrationdependent manner. b-d Cells were infected with adenovirus (Ad)-carrying genes encoding wild-type (Wt) ALK7 (open triangles), dominant negative (DN) ALK7 (open diamonds) or constitutively active (CA)

ALK7 (crosses) $\left(\sim 3 \times 10^{9} \mathrm{pfu} / \mathrm{ml}\right.$ yields $>99 \%$ infection rate; MOI $\sim 10$ ), as described in Materials and methods. Ad-GFP was used as the control infection and AdGFP-infected cells (GFP, filled squares) showed no significant difference compared with noninfected cells (Non, filled diamonds). Cell growth (b) and death (c) were determined by cell counts and Trypan Blue exclusion. Proliferation was measured by ${ }^{3} \mathrm{H}$-thymidine incorporation (d). Twenty-four hours after viral infection, cells were rinsed once with serumfree medium and then incubated with the culture medium and ${ }^{3} \mathrm{H}$-methylthymidine for $4 \mathrm{~h}$. Data represent mean \pm SEM $(n=3) .{ }^{*} p<0.05,{ }^{* *} p<0.01$
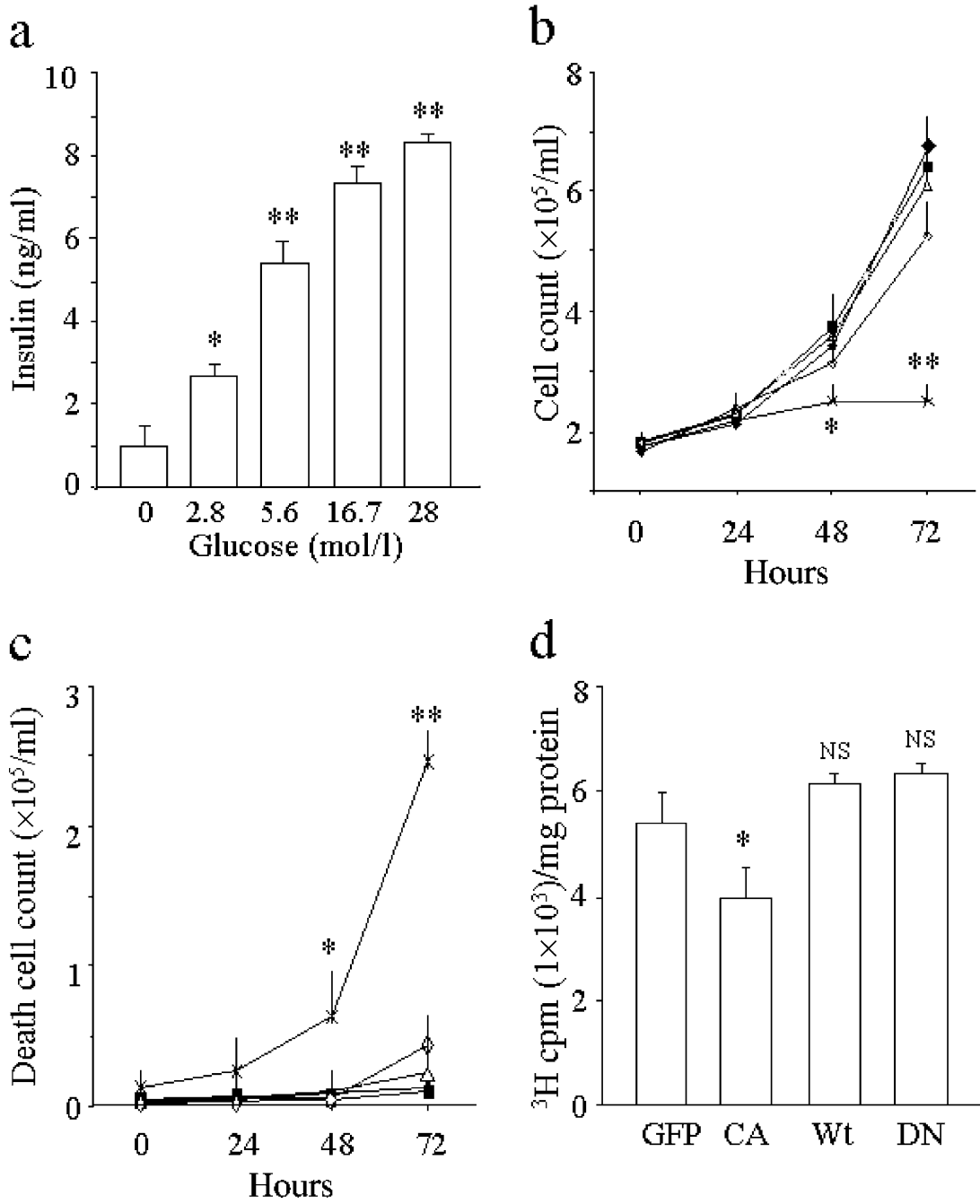

d

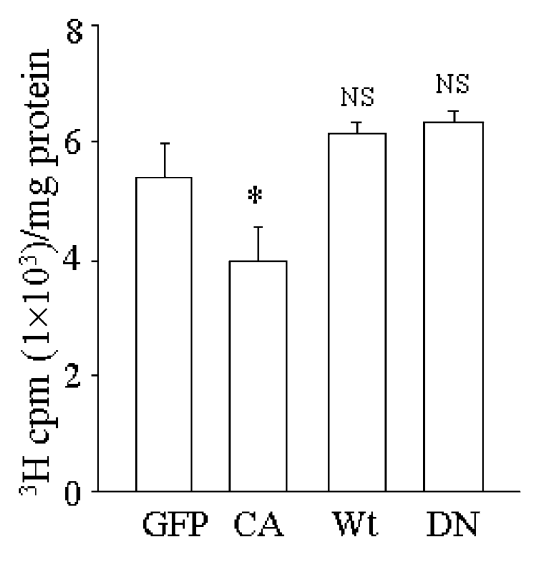


and a $72 \mathrm{kDa}$ band in INR1G9 cells. ALK7 expression was not detected in COS cell lysates, which were used as a negative control (Fig. 2b).

We examined the cellular localisation of ALK7 by immunocytochemical studies. We detected ALK7 in the cytoplasmic compartment and plasma membrane in INS-1 cells (Fig. 3a,b), dispersed rat insulin-positive-islet cells (Fig. 3c) and glucagon-positive islet cells (Fig. 3d). Some of the staining for ALK7 overlapped with the staining for insulin and glucagon. In insulin-containing islet cells, ALK7 appeared to be both cytoplasmic and associated with the plasma membrane (Fig. 3c, arrows), but in the glucagon-containing islet cells ALK7 was mostly cytosolic (Fig. 3d), suggesting that different ALK7 isoform(s) are expressed in different kinds of islet cells. The goat polyclonal anti-ALK7 (Fig. 3b) and the mouse monoclonal anti-ALK7 antibodies (Fig. 3a) had identical staining patterns, thus verifying the specificity of the anti-ALK7 antibodies. ALK7 staining was absent in COS cells, which were used as a negative control (data not shown).

ALK7 suppresses cell growth and induces cell death in INS-1 cells

Detection of ALK7 in islet beta cells and the INS-1 cell line suggests that ALK7 plays a role in regulating the activity a
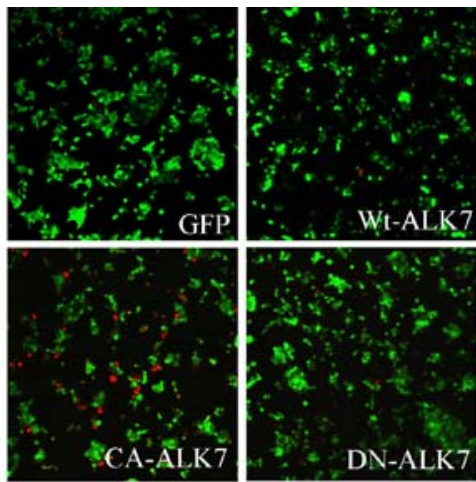

c

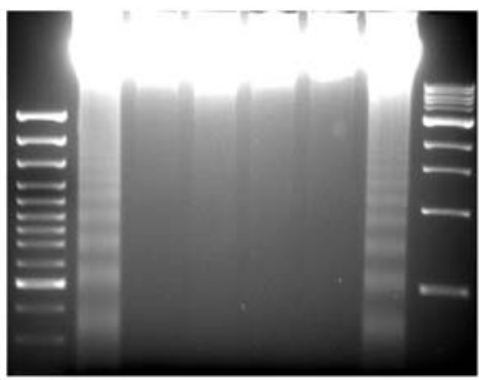

L $\mathrm{H}_{2} \mathrm{O}_{2}$ Non GFP Wt DN CA L and function of these cells. INS- 1 cells are a widely used beta cell model $[35,36]$ to study beta cell function. To study the role of ALK7 in modulating beta cell proliferation and apoptosis, we infected INS-1 cells with adenoviral vectors (Ad) carrying cDNAs encoding GFP-tagged Wt-ALK7 or CA-ALK7 or DN-ALK7. Under our culture conditions, a doubling time of 55-60 h was typically seen, as was glucose-stimulated insulin secretion from INS-1 cells via a glucose concentration-dependent mechanism (Fig. 4a). Pilot studies were done to establish optimal infection conditions. It was found that a viral concentration of $\sim 3 \times 10^{9} \mathrm{pfu} / \mathrm{ml}$ yields a $>99 \%$ infection rate (multiplicity of infection [MOI] 10) in INS-1 cells as determined by the GFP (not shown). This viral concentration was used in all infections described in this study. We found in INS-1 cells that viral infection by Ad-CA-ALK7 resulted in a significant reduction in cell numbers (Fig. 4b) and increased cell death $48 \mathrm{~h}$ after infection; cell death increased thereafter over the course of the cell-growth studies (Fig. 4c), as determined by cell counts and Trypan Blue exclusion. In contrast, control infection (Ad-GFP) or infecting cells with Ad-Wt-ALK7 or Ad-DN-ALK7 showed no significant effects on the growth (Fig. 4b) or death (Fig. 4c) of INS-1 cells compared with non-infected control cells (Fig. 4b,c). These results suggest that activation of ALK7 causes inhibition of cell growth and induction of cell death in INS-1 cells.

b

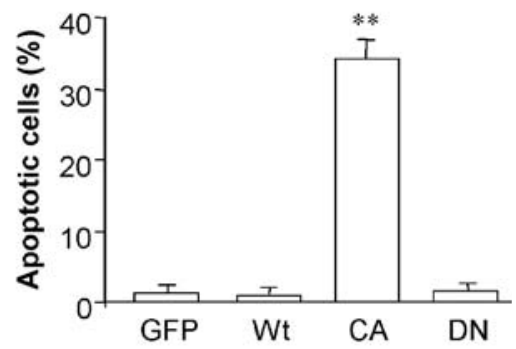

Fig. 5 Adenoviral CA-ALK7 infection inhibits proliferation and promotes apoptosis. a In situ cell death detection. Cells were infected with adenovirus (Ad)-carrying genes encoding either WtALK7, DN-ALK7 or CA-ALK7 for $24 \mathrm{~h}$. Ad-GFP was used as the control. Apoptosis of INS-1 cells was determined $24 \mathrm{~h}$ after viral infection by TUNEL staining using the In Situ Cell Death Detection Kit, TMR red (Roche Diagnostics) and visualised by fluorescent microscope (red, apoptotic cells). The data shown are typical of five similar experiments. A minimum of 600 cells were counted for each condition per experiment. b Proportion of apoptotic cells (\%). Data are mean $\pm \operatorname{SEM}(n=5, * * p<0.01)$. c DNA degradation analysis Infections were performed as described above. Floating and adherent cells from each infection were combined and pelleted and visualised for DNA fragmentation. Cells treated with $\mathrm{H}_{2} \mathrm{O}_{2}$ $(50 \mu \mathrm{mol} / 1,24 \mathrm{~h})$ were used as a positive control. The blot is typical of five independent experiments 
In order to further determine the effects of ALK7 on INS-1 cell proliferation, DNA synthesis was measured using ${ }^{3} \mathrm{H}$-methylthymidine incorporation. As shown (Fig. 4d), infection with Ad-CA-ALK7 inhibited INS-1 cell proliferation by $\sim 30 \% 24 \mathrm{~h}$ after infection $(p<0.05$, $n=3)$. Again, no significant effect on cell proliferation was observed in the control-infected cells (GFP) or the cells infected by Ad-Wt-ALK7 or Ad-DN-ALK7 (Fig. 4d). These results further indicate that ALK7-inhibited cell growth results from inhibition of cell proliferation.

To further examine whether ALK7-induced cell death is due to apoptosis, we performed cell apoptotic assays using TUNEL staining [37]. As shown (Fig. 5), $24 \mathrm{~h}$ after viral infection we found that overexpression of Ad-CA-ALK7 greatly increased INS-1 cell apoptosis. The number of cells undergoing apoptosis was $2-3 \%$ in the control and WtALK7- and DN-ALK7-infected cells and 35\% in the CAALK7-infected cells (Fig. 5a,b; $p<0.05, n=5$ ). Of note, apoptosis was detected about $24 \mathrm{~h}$ earlier than cell death, which reflects the natural process of apoptosis. In addition, a DNA ladder assay was used to determine the characteristic pattern of apoptosis [38]. As a positive control, INS-1 cells treated with $50 \mu \mathrm{mol} / 1 \mathrm{H}_{2} \mathrm{O}_{2}$ or $0.4 \mathrm{mmol} / \mathrm{l}$ palmitate (not shown) for $24 \mathrm{~h}$ produced a characteristic DNA laddering pattern (Fig. 5c); this was also detected in the cells infected with Ad-CA-ALK7, but not in the cells infected with Ad-Wt-ALK7, Ad-DN-ALK7 or Ad-GFP and non-infected control INS-1 cells (Fig. 5c). These findings indicate that activation of ALK7-induced INS-1 cell death occurs via apoptosis.
Fig. 6 Glucose- and fatty acidinduced beta cell apoptosis is associated with elevation of endogenous ALK7 activity. INS-1 cells $(\mathbf{a}, \mathbf{b})$ or rat islets $(\mathbf{c}, \mathbf{d})$ were incubated with various concentrations of glucose and/or $0.4 \mathrm{mmol} / 1$ palmitate for $24 \mathrm{~h}$. Total mRNAs were extracted and ALK7 transcripts were examined by RT-PCR (GAPDH as control) $(\mathbf{a}, \mathbf{c})$. Cell lysates $(\mathbf{b}, \mathbf{d})$ were subjected to western blot analysis using anti-ALK7, anticaspase- 3 antibodies or antibeta-actin (control). The data shown are typical of three or four similar experiments. Bar graphs show mean \pm SEM for densitometry scans for specified proteins. Pal palmitate, Glu glucose a

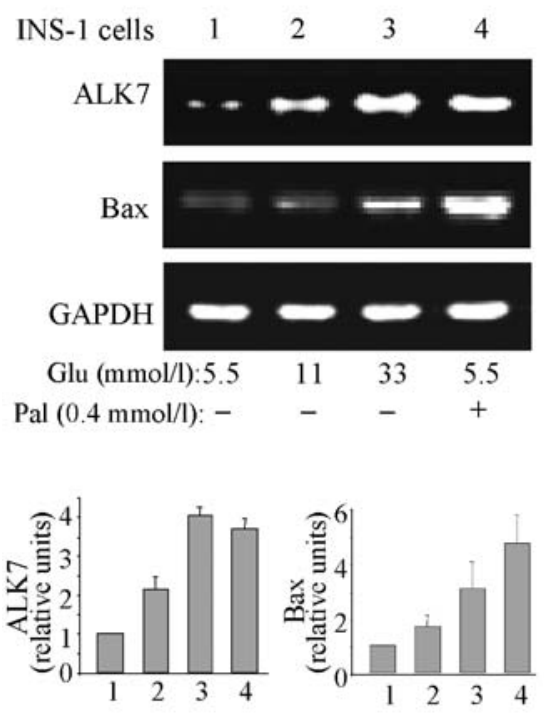

c

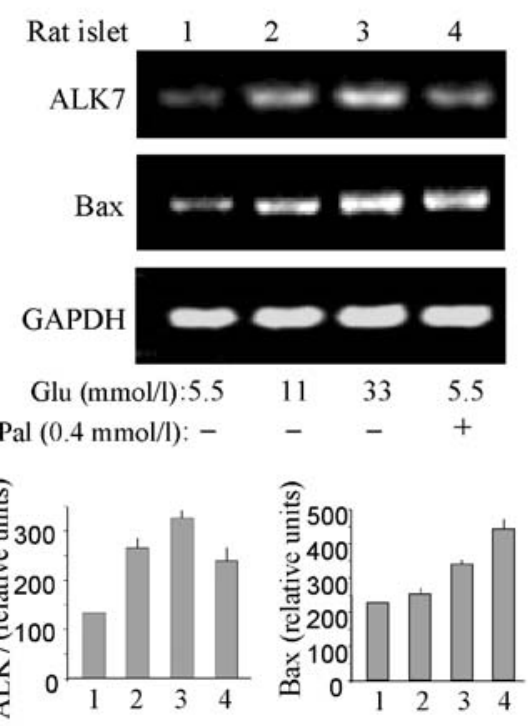

b

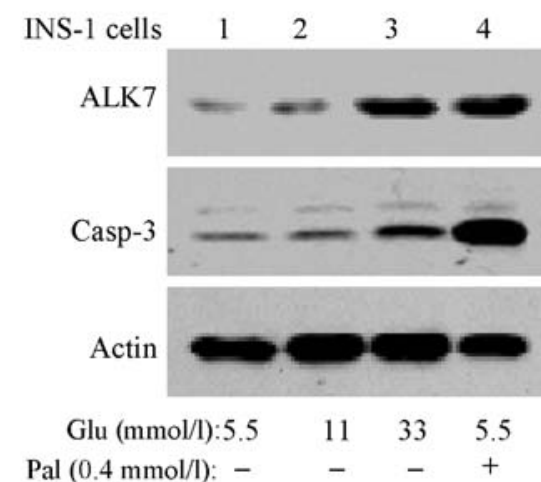
Pal $(0.4 \mathrm{mmol} / \mathrm{l}):-c_{1} \quad-\quad+\quad+$

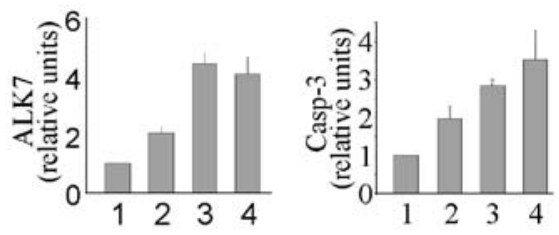

d
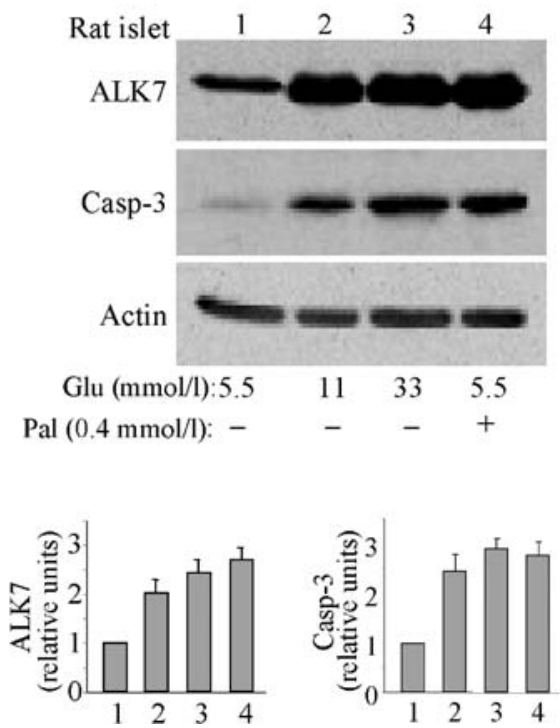
Glucose- and fatty acid-induced beta cell apoptosis is associated with elevation of endogenous ALK7 activity

To examine the phenomenon in a more physiological context, we studied the effect of glucose and fatty acid (palmitate) on the modulation of endogenous ALK7 expression and apoptosis in isolated rat islets and INS-1 cells. INS-1 cells were exposed to an elevated glucose concentration and the endogenous ALK7 expression levels and cell apoptosis were determined using RT-PCR and western blotting. Increasing the glucose concentration increased endogenous ALK 7 both at transcript and protein levels (by $\sim 4$-fold) and concomitantly increased expression of BAX transcript and active caspase-3 protein (by $\sim 4$-fold) (Fig. 6a,b). In the presence of $5.5 \mathrm{~mol} / 1$ glucose, treatment with $0.4 \mathrm{mmol} / \mathrm{l}$ palmitate $(24 \mathrm{~h})$ resulted in a comparable enhancement of ALK7 expression and increased apoptosis in the INS-1 cells (Fig. 6a,b). Similar results were obtained in isolated rat islets; elevated glucose and/or palmitate increased endogenous ALK7 transcripts and protein by $\sim 2$-fold and increased expression of BAX transcripts and active caspase-3 protein by $\sim 2$-fold, respectively (Fig. 6c,d). These results suggest that glucose and/or palmitate induced caspase-3 activation in beta cells through activation of endogenous ALK7.

To confirm that ALK7-mediated beta cell death is via ALK7 activation but not a consequence of increased levels of protein expression, we asked if palmitate-induced cell death can be prevented by Ad-DN-ALK7. Western blotting using anti-ALK7 antibodies indicated that infection with Ad-Wt-ALK7 or Ad-DN-ALK7 resulted in significantly increased expression levels of ALK7 in INS-1 cells, compared with cells infected with Ad-GFP (Fig. 7a,b) and non-infected cells (not shown). As expected, treatment with palmitate $(0.4 \mathrm{mmol} / \mathrm{l}, 24 \mathrm{~h})$ significantly increased INS-1 cell death when examined by western blotting using antibodies against the active form of caspase- 3 . This effect was markedly attenuated in cells infected with Ad-DNALK7 (Fig. 7a,c). Prevention of INS-cell death by expression of DN-ALK7 further suggests that ALK7 is an important mediator of palmitate-induced cell death in INS-1 cells.

\section{Activation of ALK7 suppresses Akt activation}

Recent studies have demonstrated an important role for Akt in modulating islet beta cell survival and apoptosis and have shown that many signalling pathways seem to converge on Akt (for a review see [39]). We therefore addressed the possibility that ALK7 activation might affect Akt signalling in modulating its actions on cell proliferation and apoptosis. Akt activation was evaluated by western blotting using anti-Akt or anti-phospho-Akt antibodies. As shown, adenoviral infection with various ALK7 constructs had no significant effect on total Akt expression in INS-1 cells (Fig. 8a). Treatment with $100 \mathrm{nmol} / \mathrm{l}$ insulin for $5 \mathrm{~min}$ resulted in strong activation of Akt and this effect was partially blocked by infection with Ad-CA-ALK7 (Fig. 8b). In contrast, infection with GFP, Wt-ALK7 or DN-ALK7 had no effect on insulininduced Akt activation (Fig. 8b). This suggests that activation of ALK7 may perturb the Akt signalling pathway. Apoptosis in the presence of wild-type and mutant forms of
Fig. 7 Fatty acid-induced beta cell apoptosis is diminished in INS- 1 cells infected with adenoviral (Ad)-DN-ALK7. Cells infected with Ad-WT-ALK7, Ad-DN-ALK7 (or Ad-GFP as control, Ctrl) were incubated with $5 \mathrm{mmol} / 1$ glucose alone or with $0.4 \mathrm{mmol} / \mathrm{l}$ palmitate for $24 \mathrm{~h}$. a Cell lysates were subjected to western blot analysis using anti-ALK 7, anti-active caspase-3 antibodies or antibeta-actin (control). The data shown are typical of three or four similar experiments. $\mathbf{b}$, Mean \pm SEM values for densitometry scans for ALK7 $(n=3$, $* * p<0.01)$ and active caspase-3 $\left(n=3, * * p<0.01,{ }^{*} p<0.05\right)$ proteins
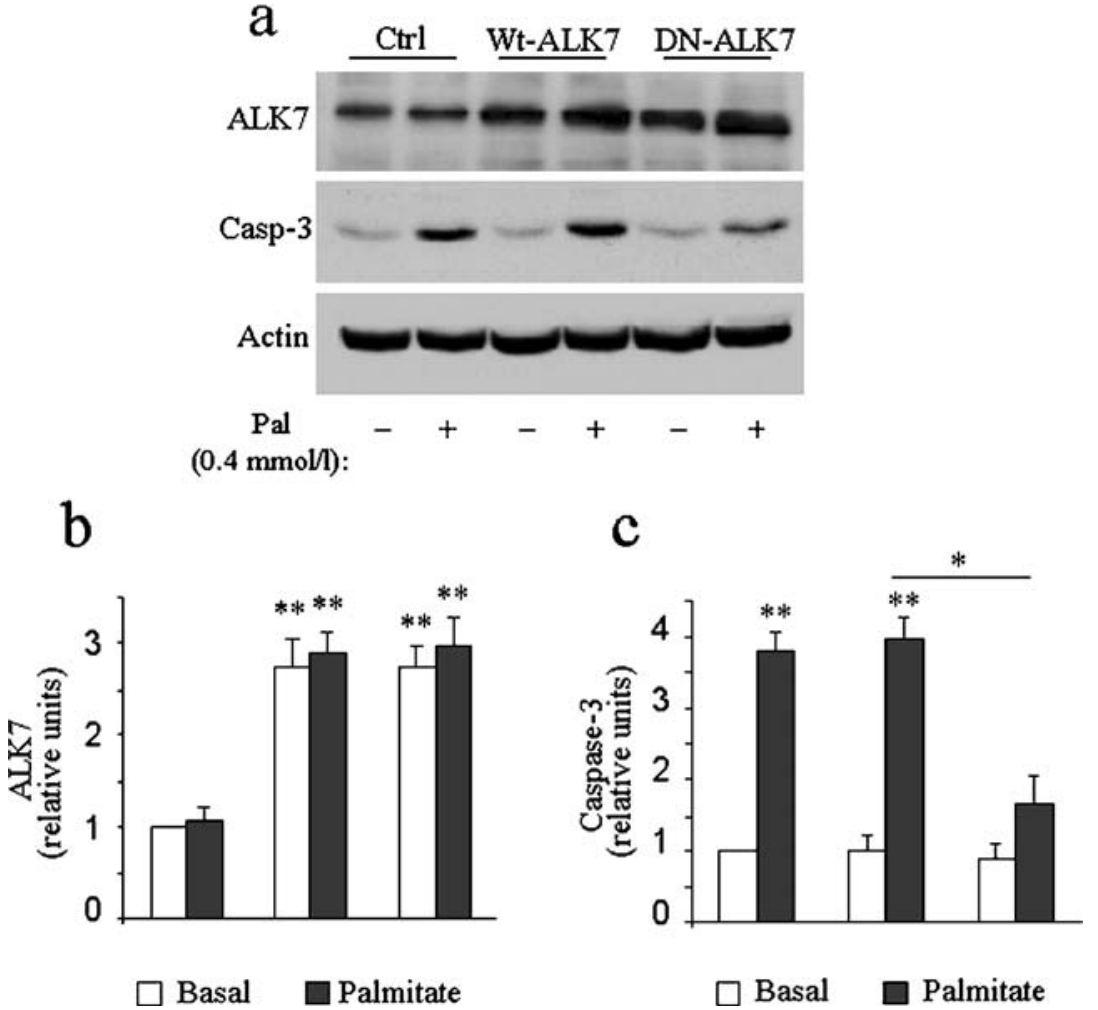

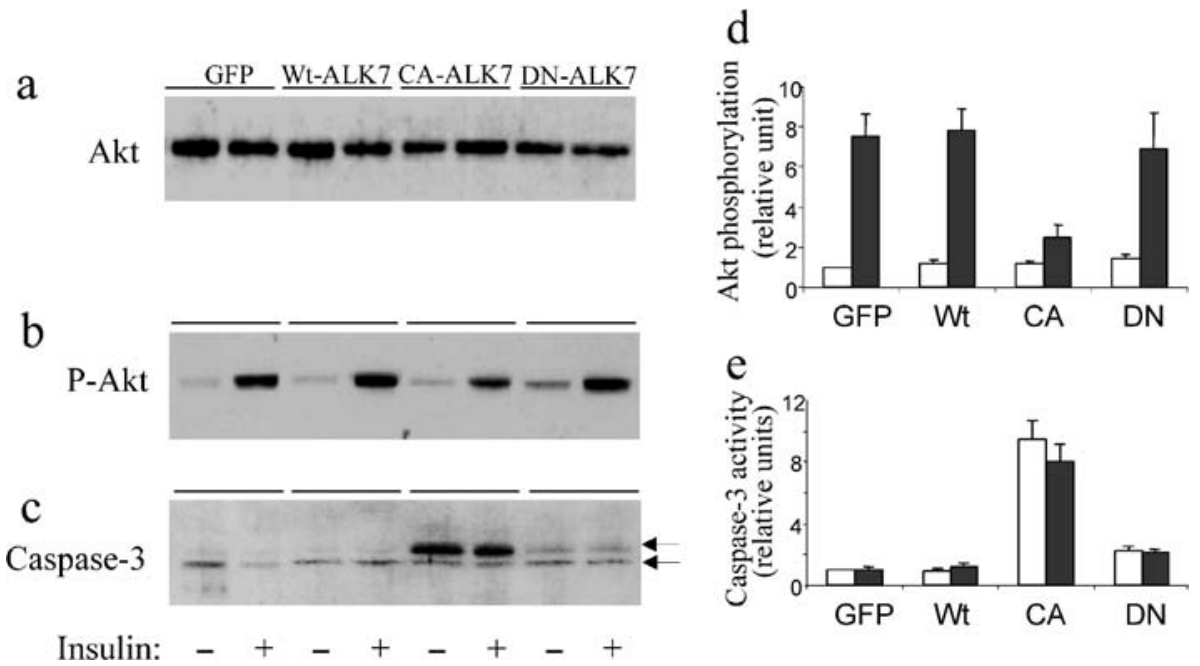

Fig. 8 Expression of CA-ALK7 suppresses Akt activation and activates caspase-3. INS-1 cells infected with various adenoviral ALK 7 constructs $\left(\sim 3 \times 10^{9} \mathrm{pfu} / \mathrm{ml}\right.$; MOI $\left.\sim 10\right)$ were serum-starved for $2 \mathrm{~h}$ and treated with or without $100 \mathrm{nmol} / \mathrm{l}$ insulin for $5 \mathrm{~min}$. Cell lysates were subjected to western blot analysis using anti-Akt (a),

ALK7 was further explored by examining the expression levels of caspase-3. Western blot analysis, using an antibody against active caspase- 3 , demonstrated an increase in the content of the bioactive form of this apoptotic enzyme ( 9 -fold, $p<0.01, n=5$ ) in cells infected by Ad-CA-ALK7 (Fig. 8c). Viral infection with Ad-Wt-Akt, Ad-DN-Akt or Ad-GFP was found to have no effect on the level of the bioactive form of caspase-3 (Fig. 8c). Elevation of ALK7 activity resulted in reduced Akt activation and increased caspase-3 activation, suggesting that ALK7-induced apoptosis is at least partially due to attenuation of Akt activation.

ALK7-induced apoptosis is mediated by Smad2caspase- 3 pathways and prevented by Akt

ALK7 activation is known to initiate the R-Smad cascade in the induction of apoptosis, involving phosphorylation of $\operatorname{Smad} 2 / 3$ proteins [7]. To explore whether Smad2 is involved in ALK7 action in INS-1 cells, we examined whether ALK7 could induce Smad2 phosphorylation and whether DN-Smad2 could block the pro-apoptotic action of ALK7. To this end, we combined adenoviral infection and plasmid transfections (Fig. 9). As shown, infection of INS-1 cells with Ad-CA-ALK7 (but not Wt- or DN-ALK7) produced strongly activated caspase- 3 which was abolished by co-expression of DN-Smad2 (Fig. 9a).

Since the activation of ALK7 led to inhibition of insulininduced Akt activation (Fig. 8), we sought to determine whether Akt interacts with the ALK7/Smad signalling cascade. To do this, INS 1 cells were first transiently transfected with control pcDNA3, DN ALK7, DN Smad2 or CA Akt plasmid and subsequently infected with AdALK7 $6 \mathrm{~h}$ after the transfection for an additional 18-20 h. As shown (Fig. 9b), pronounced levels of phospho-Smad2
anti-phospho-Akt antibodies (b) or anti-active caspase-3 antibody (c), where the arrows indicate 19 and $21 \mathrm{kDa}$, respectively. The data shown are typical of three similar experiments. d, e Mean \pm SEM for densitometry scans for phospho-Akt and active caspase-3. Open bars basal; shaded bars insulin

protein were detected in the cells infected with CA-ALK7 compared with the cells infected with Ad-Wt-ALK7 or AdGFP. However, this Ad-CA-ALK7-mediated Smad2 phosphorylation was markedly attenuated in cells co-expressing DN-ALK7 or DN-Smad2 (Fig. 9b). Activation of Akt (by

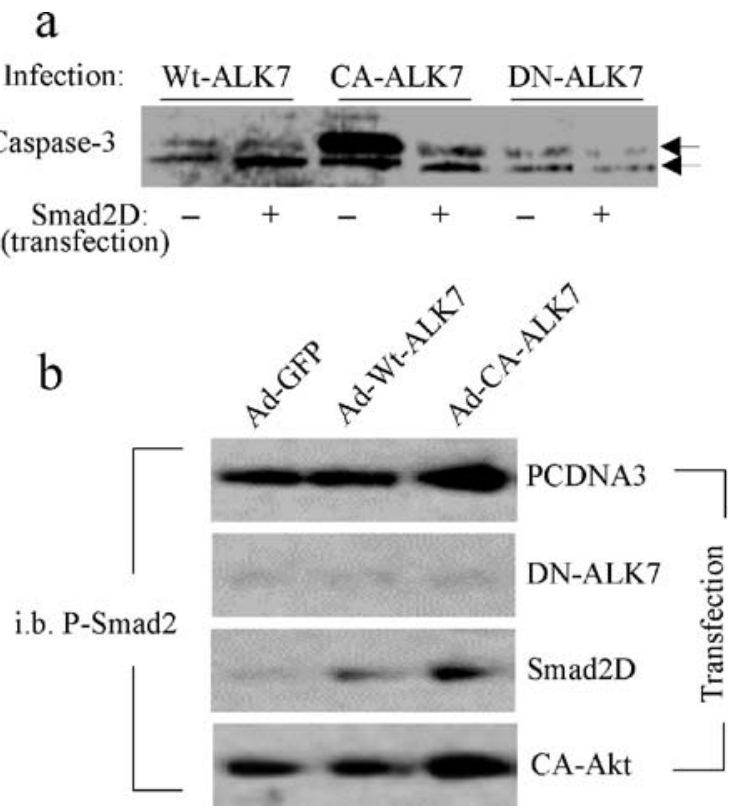

Fig. 9 Expression of dominant negative Smad2 reduces ALK7mediated apoptosis. INS-1 cells were first transfected with DNSmad2 (a) or (b) control PCDNA3, DN-ALK7, Smad2-deficient or CA-Akt plasmids using Lipofectamine 2000 Plus, which consistently yields an $80-85 \%$ transfection rate, as indicated by GFP expression. Six hours after transient transfection, the cells were washed and further incubated with adenoviral constructs of ALK7 or GFP as indicated for an additional $18-20 \mathrm{~h}$. The proteins were then extracted from the cells and analysed by western blotting for active (a) caspase-3 (arrows indicate 19 and $21 \mathrm{kDa}$, respectively) or (b) phospho-Smad2 levels 


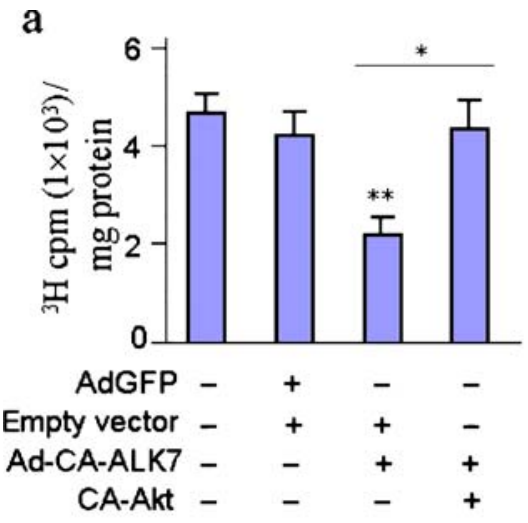

b

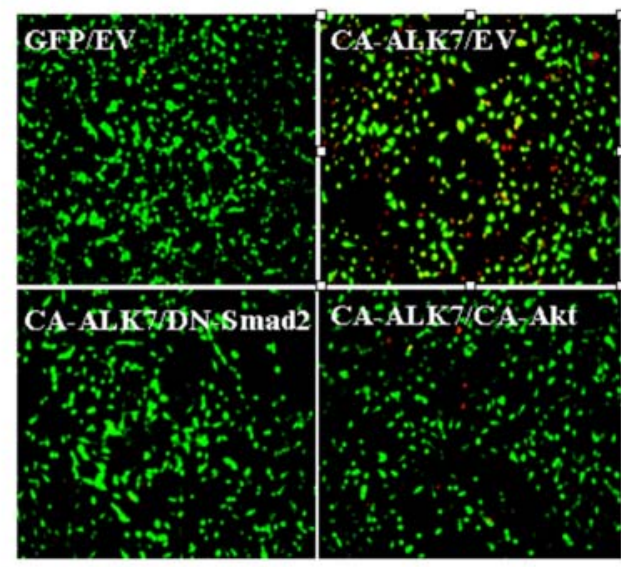

c

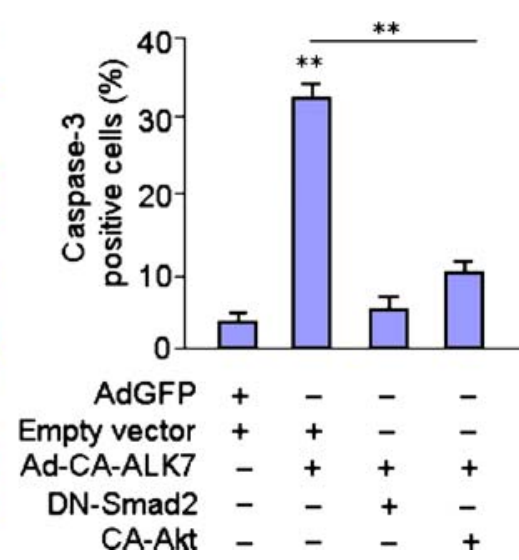

Fig. 10 Elevation of Akt kinase activity reverses CA-ALK7induced reductions in INS-1 cell proliferation and prevents cell apoptosis. (a) Bar histogram summarising the results of proliferation assays in INS-1 cells infected with adenoviral (Ad)-CA-ALK7 as detected by ${ }^{3} \mathrm{H}$-thymidine incorporation. Co-expression of constitutively active Akt (CA-Akt) in the cells infected with Ad-CA-ALK7 was found to restore ${ }^{3} \mathrm{H}$-thymidine incorporation to the control AdGFP-infected level. Data are mean $\pm \operatorname{SEM}\left(n=3 ;{ }^{*} p<0.05,{ }^{*} p<0.01\right)$. (b) Typical fluorescent microscopic images of INS-1 cells stained for active caspase-3 (red) $24 \mathrm{~h}$ following the co-expression of GFP-

CA-Akt) did not obviously affect Ad-CA-ALK7-induced phospho-Smad2 protein levels (Fig. 9b).

To further determine whether an elevation of Akt activity might affect ALK7-induced growth inhibition and enhanced beta cell apoptosis, we performed experiments that combined viral infection with Ad-CA-ALK7 constructs (Ad-GFP as control) and transient transfections either with empty vectors as control or CA-Akt, and examined cell proliferation $\left({ }^{3} \mathrm{H}\right.$-thymidine assay) and apoptosis (caspase3 staining) in INS-1 cells. Combined viral infection of AdGFP constructs and transfection of empty vectors had no significant affect on ${ }^{3} \mathrm{H}$-thymidine incorporation into DNA in INS-1 cells. Infection with Ad-CA-ALK7 significantly reduced cell proliferation by $46 \%$ in INS- 1 cells (Fig. 10a; $p<0.05$ ); this was fully blocked by cotransfection with CAAkt. Under these experimental conditions, the apoptosis rate was evaluated by caspase- 3 immunostaining. While Ad-GFP and empty vectors had no noticeable effects on INS-1 apoptosis, as expected, viral infection of CA-ALK7 tagged Ad-CA-ALK7 and Samd2D or CA-Akt constructs (GFP, green). INS-1 cells were infected with the adenovirus $\left(1 \times 10^{9} \mathrm{pfu} /\right.$ $\mathrm{ml}$; MOI $\sim 10$ ) followed by transfection (Lipofectamine 2000 Plus) of control empty or DN-Smad2 or CA-AKT vectors (using $2.5 \mu \mathrm{g}$ cDNAs). c Bar histogram showing summation of active caspase-3 staining from at least three or four separate fields taken from each experiment $(n=3)$. A minimum of 600 cells were counted for each condition/treatment and the number of active caspase-3-positive cells (red) was expressed as the ratio of the total number of GFPpositive cells (green). Data are mean $\pm \operatorname{SEM}(n=3 ; * * p<0.01)$

lead to increased apoptosis (Fig. 10b, 3.9 \pm 0.9 vs $32.1 \pm$ $1.4 \% ; p<0.01, n=3$ ), which was significantly attenuated by co-expression of DN-Smad2 (Fig. 10b, 5.6 $\pm 1.3 \%$; $p<0.01$, $n=3$ ). The Ad-CA-ALK7 infected cells cotransfected with CA-Akt also showed a marked reduction in caspase-3 staining levels (Fig. 10b, $8.7 \pm 1.2 \% ; p<0.01, n=3$ ). These results suggest that elevation of Akt kinase activity prevents ALK7-induced reduction in beta cell growth and beta cell apoptosis.

\section{Discussion}

We examined the expression and function of ALK7 in insulin-secreting beta cell lines and rat islet cells. We detected ALK7 transcripts and proteins in the rat pancreatic islet cells and INS-1 cells. The findings are in good agreement with previous studies by Watanabe et al. [7], who detected ALK7 mRNA in MIN6 cells, and by 
Tsuchida and colleagues [28], who demonstrated that ALK7 proteins were localised to insulin-positive cells in murine pancreatic tissue. We also detected ALK7 expression in the alpha cells, although the cellular distribution and the molecular weight differed from ALK7 found in the beta cells. It is thus possible that ALK7 isoforms exist in different types of islet cell. Studies in human placenta have revealed that there are four ALK7 transcripts derived from alternative splicing of the gene encoding ALK7 [16, 20, 21]. In our RT-PCR experiments, we used primers specific to ALK7 transcript 4 (16) and hence only a single band of $500 \mathrm{bp}$ is visualised.

We generated GFP-tagged adenoviral constructs encoding wild-type ALK7 or various ALK7 mutants as a strategy to dissect the specific actions of ALK7 in the beta cells. INS- 1 cells overexpressing Ad-CA-ALK7 showed a significant reduction in cell number and increased cell death. DNA synthesis and apoptotic assays indicated that this was due to inhibition of cell proliferation and increased apoptosis. These results are in good agreement with previous findings that demonstrated that activation of ALK7 inhibited cell proliferation and induced apoptosis in a variety of non-pancreatic cells $(9,20-22)$. Infection of IN-R1-G9 cells with Ad-CA-ALK7 (MOI 10) did not cause any obvious apoptosis to occur (not shown). The beta cells were more susceptible to ALK7-mediated cell death than the alpha cells, which may be explained by the different isoforms expressed by the different types of islet cell (Figs. 2 and 3).

Elevated glucose concentrations or palmitate increased endogenous ALK7 expression and apoptosis in both INS-1 and isolated rat islet cells, suggesting that ALK7 induces beta cell apoptosis. The elevated concentrations of glucose and/or palmitate have been shown to induce islet beta cell apoptosis under certain conditions [40-42]. The effect of glucose and/or palmitate on beta cell turnover probably involves activation of the apoptotic mitochondrial pathway [41] by upregulating the Fas receptor [40, 41]. It is thus particularly interesting to identify the interactions of ALK7 with these signalling pathways mediating gluco- and/or lipotoxicity-induced islet beta cell apoptosis.

To our knowledge, this is the first report demonstrating the specific cellular events activated by ALK7 that modulate beta cell proliferation and apoptosis. Our results show that ALK7-induced apoptosis in INS-1 cells involves proteolytic cleavage of proform caspase-3, one of the primary mediators of apoptosis [43]. The prominent upregulation of active caspase-3 in Ad-CA-ALK7-infected INS-1 cells was strongly suppressed by the cotransfection of mutant DN-Smad2, suggesting that ALK7-induced INS1 apoptosis is mediated via a Smad-dependent mechanism. This finding is consistent with the recent reports demonstrating that the Smad2/3-dependent pathway mediates ALK7-induced apoptosis in trophoblast cells [21] and ovarian cancer cells [20]. Activation of caspase-3 by ALK 7 has also been reported in human hepatocytes [22], trophoblasts [21] and epithelial ovarian cancer cells [20].

In this study we demonstrated that a downstream event activated by ALK7 abolishes insulin-induced Akt activa- tion, suggesting that the Akt pathway participates in ALK7 signalling to regulate beta cell proliferation and apoptosis. In order to confirm the role of Akt in ALK7-induced growth inhibition and apoptosis in INS-1 cells, we performed Ad-CA-ALK7 infections followed by transient transfections with CA-Akt. Indeed, elevation of Akt kinase activity by overexpression of CA-Akt significantly attenuated ALK7-induced growth inhibition and apoptosis in INS-1 cells. However, elevation of Akt activity by CA-Akt did not attenuate ALK7-induced Smad2 phosphorylation. This finding suggests that ALK7-induced Smad2 activation does not require the inactivation of Akt. It is possible, therefore, that ALK7-Akt signalling is distinct from the ALK7-Smad2/3 pathway. Akt is an important signalling molecule that plays diverse roles in mammalian cells, including promoting cell growth and preventing apoptosis [44]. In the INS- 1 cell or its analogue, Akt activation plays an important role in promoting cell survival [45] and inhibiting apoptosis induced by elevated glucose and palmitate [46].

In vivo studies also proved that Akt signal transduction is critical in controlling islet beta cell survival [39]. In type 2 diabetic $d b / d b$ mouse models, Akt expression is suppressed, and accompanied by enhanced beta cell apoptosis and reduced beta cell mass [47]. In contrast, transgenic mice overexpressing Akt displayed increased beta cell mass associated with improved glucose tolerance and resistance to experimental diabetes [48]. Therefore, identification of the role of Akt in mediating the ALK7 signalling pathway that modulates beta cell function may offer useful insights into the development of beta cell dysfunction and the subsequent onset of diabetes.

Crosstalk between non-Smad signalling molecules and ALK7 signalling pathways has been reported to occur in other cells, suggesting there are complex features of ALK7 pathways in modulating cell function [1,3]. Under certain circumstances, ALK 7 induces apoptosis through activation of the traditional TGF- $\beta$ pathway. This results in new gene transcription and protein kinase activation, thereby initiating the cellular stress death pathway and ultimately leading to apoptosis. For example, in rat hepatoma cells ALK7 induces apoptosis through activation of MAPKs, JNK and p38 in a Smad3-dependent manner, which contributes to crosstalk with the cellular stress death pathway and ultimately leads to apoptosis [22]. However, this seemed not to be the case with regard to the involvement of Akt kinase activity in mediating ALK7 actions in the death pathway in INS-1 cells, since the level of Akt protein was not affected following ALK7 activation. It is likely that Akt, in parallel with the Smad pathway, mediates ALK7 signals to the downstream death effectors (Fig. 10). In epithelial cells, PI3K-Akt signalling is required for TGF- $\beta$ induced transcriptional responses [49]. Moreover, antiapoptotic protein(s) interact with the ALK7 signalling pathway. In epithelial ovarian cancer cells, activation of ALK7 resulted in reduced expression of X-chromosome linked inhibitor of apoptosis (XIAP), a member of the inhibitor of apoptosis proteins family of potent caspase suppressors [50], at both the mRNA and the protein level, 
suggesting that suppression of XIAP might contribute to ALK7-induced apoptosis in these cells [20]. By direct targeting, XIAP inhibits apoptosis mediated by the caspase family [51]. It has been suggested that Akt is required in cancer cells for transcriptional regulation of XIAP and that the endogenous Akt-XIAP pathways are critical in controlling cell survival by preventing ERK stress-induced cell death [52]. Identification of ligand(s) for ALK7 in the islets and determination of the precise role of Akt-XIAP in mediating ALK7 signals is ongoing in our laboratory.

Taken together, our results suggest an important role of ALK7 in modulating beta cell function. ALK7-induced inhibition of beta cell proliferation and increased apoptosis occurs, at least in part, via the suppression of Akt activation and activation of the Smad2-caspase-3 pathway(s). Of particular interest will be future studies to dissect the ALK7 signalling pathway in beta cells and to determine in animal models whether ALK7-induced beta cell apoptosis is one of the processes that leads to the development of beta cell dysfunction and the subsequent onset of diabetes. The findings should provide valuable information on the mechanisms underlying ALK7-regulated beta cell proliferation and apoptosis, thereby enhancing our understanding of the biochemical events in the regulation of beta cell mass under physiological and pathological conditions.

Acknowledgements The authors would like to thank J. R. Woodgett (University of Toronto, Toronto, Canada) for providing Akt vectors and R. Derynck (University of California, San Francisco) for dominant negative Smad2 vectors. This work was supported by grants from the Canadian Institute for Health Research (CIHR) and Banting and Best Diabetes Centre (Toronto) to Q. Wang. M. Kumar is a recipient of a Postdoctoral Fellowship from the Canadian Diabetes Association. Q. Wang is a Scholar of the Canadian Diabetes Association. We thank Dr P. Doherty (St Michael's Hospital, Toronto, Canada) for a critical reading of the manuscript.

\section{References}

1. Derynck R, Zhang YE (2003) Smad-dependent and Smadindependent pathways in TGF-beta family signalling. Nature 425:577-584

2. Zimmerman CM, Padgett RW (2000) Transforming growth factor beta signaling mediators and modulators. Gene 249:1730

3. Peng C, Mukai ST (2000) Activins and their receptors in female reproduction. Biochem Cell Biol 78:261-279

4. Massague J, Wotton D (2000) Transcriptional control by the TGF-beta/Smad signaling system. EMBO J 19:1745-1754

5. Attisano L, Wrana JL (2000) Smads as transcriptional comodulators. Curr Opin Cell Biol 12:235-243

6. Wrana JL, Attisano L, Wieser R, Ventura F, Massague J (1994) Mechanism of activation of the TGF-beta receptor. Nature 370:341-347

7. Watanabe R, Yamada Y, Ihara Y et al (1999) The MH1 domains of smad 2 and $\operatorname{smad} 3$ are involved in the regulation of the ALK7 signals. Biochem Biophys Res Commun 254:707-712

8. de Caestecker MP, Parks WT, Frank CJ et al (1998) Smad2 transduces common signals from receptor serine-threonine and tyrosine kinases. Genes Dev 12:1587-1592

9. Jornvall H, Blokzijl A, Ten Dijke P, Ibanez CF (2001) The orphan receptor serine/threonine kinase ALK7 signals arrest of proliferation and morphological differentiation in a neuronal cell line. J Biol Chem 276:5140-5146
10. Bakin AV, Tomlinson AK, Bhowmick NA, Moses HL, Arteaga CL (2000) Phosphatidylinositol 3-kinase function is required for transforming growth factor beta-mediated epithelial to mesenchymal transition and cell migration. J Biol Chem 275: 36803-36810

11. Vinals F, Pouyssegur J (2001) Transforming growth factor beta1 (TGF-beta1) promotes endothelial cell survival during in vitro angiogenesis via an autocrine mechanism implicating TGF-alpha signaling. Mol Cell Biol 21:7218-7230

12. Derynck R, Zhang YE (2003) Smad-dependent and Smadindependent pathways in TGF-beta family signalling. Nature 425:577-584

13. Inman GJ, Nicolas FJ, Callahan JF et al (2002) SB-431542 is a potent and specific inhibitor of transforming growth factor-beta superfamily type I activin receptor-like kinase (ALK) receptors ALK4, ALK5, and ALK7. Mol Pharmacol 62:65-74

14. Tsuchida K, Sawchenko PE, Nishikawa S, Vale WW (1996) Molecular cloning of a novel type I receptor serine/threonine kinase for the TGF beta superfamily from rat brain. Mol Cell Neurosci 7:467-478

15. Bondestam J, Huotari MA, Moren A et al (2001) cDNA cloning, expression studies and chromosome mapping of human type I serine/threonine kinase receptor ALK7 (ACVR1C). Cytogenet Cell Genet 95:157-162

16. Roberts $\mathrm{HJ}, \mathrm{Hu} \mathrm{S}$, Qiu Q et al (2003) Identification of novel isoforms of activin receptor-like kinase 7 (ALK7) generated by alternative splicing and expression of ALK7 and its ligand, Nodal, in human placenta. Biol Reprod 68:1719-1726

17. Reissmann E, Jornvall H, Blokzijl A et al (2001) The orphan receptor ALK7 and the Activin receptor ALK4 mediate signaling by Nodal proteins during vertebrate development. Genes Dev 15:2010-2022

18. Tsuchida K, Nakatani M, Matsuzaki T et al (2004) Novel factors in regulation of activin signaling. Mol Cell Endocrinol 225:1-8

19. Ryden M, Imamura T, Jornvall H et al (1996) A novel type I receptor serine-threonine kinase predominantly expressed in the adult central nervous system. J Biol Chem 271:30603-30609

20. Xu G, Zhong Y, Munir S, Yang BB, Tsang BK, Peng C (2004) Nodal induces apoptosis and inhibits proliferation in human epithelial ovarian cancer cells via activin receptor-like kinase 7. J Clin Endocrinol Metab 89:5523-5534

21. Munir S, Xu G, Wu Y, Yang B, Lala PK, Peng C (2004) Nodal and ALK7 inhibit proliferation and induce apoptosis in human trophoblast cells. J Biol Chem 279:31277-31286

22. Kim BC, van Gelder H, Kim TA et al (2004) Activin receptorlike kinase-7 induces apoptosis through activation of MAPKs in a Smad3-dependent mechanism in hepatoma cells. J Biol Chem 279:28458-28465

23. Hui H, Dotta F, Di Mario U, Perfetti R (2004) Role of caspases in the regulation of apoptotic pancreatic islet beta-cells death. J Cell Physiol 200:177-200

24. Shibata H, Kanzaki M, Takeuchi T, Miyazaki J, Kojima I (1996) Two distinct signaling pathways activated by activin $\mathrm{A}$ in glucose-responsive pancreatic beta-cell lines. J Mol Endocrinol 16:249-258

25. Ueda Y (2000) Activin A increases Pax4 gene expression in pancreatic beta cell lines. FEBS Lett 480:101-105

26. Zhang YQ, Zhang H, Maeshima A et al (2002) Up-regulation of the expression of activins in the pancreatic duct by reduction of the beta-cell mass. Endocrinology 143:3540-3547

27. Yamaoka T, Idehara C, Yano M et al (1998) Hypoplasia of pancreatic islets in transgenic mice expressing activin receptor mutants. J Clin Invest 102:294-301

28. Tsuchida K, Nakatani M, Yamakawa N, Hashimoto O, Hasegawa Y, Sugino H (2004) Activin isoforms signal through type I receptor serine/threonine kinase ALK7. Mol Cell Endocrinol 220:59-65 
29. Drucker DJ, Campos R, Reynolds R, Stobie K, Brubaker PL (1991) The rat glucagon gene is regulated by a protein kinase A-dependent pathway in pancreatic islet cells. Endocrinology 128:394-400

30. Gaisano HY, Huang X, Sheu L et al (1999) Snare protein expression and adenoviral transfection of amphicrine AR42J. Biochem Biophys Res Commun 260:781-784

31. He TC, Zhou S, da Costa LT, Yu J, Kinzler KW, Vogelstein B (1998) A simplified system for generating recombinant adenoviruses. Proc Natl Acad Sci USA 95:2509-2514

32. Wang Q, Li L, Xu E, Wong V, Rhodes C, Brubaker PL (2004) Glucagon-like peptide-1 regulates proliferation and apoptosis via activation of protein kinase B in pancreatic INS-1 beta cells. Diabetologia 47:478-487

33. El Kholy W, Macdonald PE, Lin JH et al (2003) The phosphatidylinositol 3-kinase inhibitor LY294002 potently blocks $\mathrm{K}(\mathrm{V})$ currents via a direct mechanism. FASEB J 17: $720-722$

34. Crowston JG, Healey PR, Maloof A, Allan B (2002) Quantifying corneal endothelial cell death. Br J Ophthalmol 86: 1068

35. Poitout V, Olson LK, Robertson RP (1996) Insulin-secreting cell lines: classification, characteristics and potential applications. Diabetes Metab 22:7-14

36. Asfari M, Janjic D, Meda P, Li G, Halban PA, Wollheim CB (1992) Establishment of 2-mercaptoethanol-dependent differentiated insulin-secreting cell lines. Endocrinology 130:167178

37. Liu X, Drognitz O, Neeff H, Benz S, Hopt UT (2004) Apoptosis is caused by prolonged organ preservation and blocked by apoptosis inhibitor in experimental rat pancreatic grafts. Transplant Proc 36:1209-1210

38. Fraser MJ, Tynan SJ, Papaioannou A, Ireland CM, Pittman SM (1996) Endo-exonuclease of human leukaemic cells: evidence for a role in apoptosis. J Cell Sci 109:2343-2360

39. Dickson LM, Rhodes CJ (2004) Pancreatic beta-cell growth and survival in the onset of type 2 diabetes: a role for protein kinase B in the Akt? Am J Physiol Endocrinol Metab 287: E192-E198

40. Maedler K, Spinas GA, Lehmann R et al (2001) Glucose induces beta-cell apoptosis via upregulation of the Fas receptor in human islets. Diabetes 50:1683-1690
41. Mellado-Gil J M, Aguilar-Diosdado M (2004) High glucose potentiates cytokine- and streptozotocin-induced apoptosis of rat islet cells: effect on apoptosis-related genes. J Endocrinol $183: 155-62$

42. El Assaad W, Buteau J, Peyot ML et al (2003) Saturated fatty acids synergize with elevated glucose to cause pancreatic betacell death. Endocrinology 144:4154-4163

43. Johnstone RW, Ruefli AA, Lowe SW (2002) Apoptosis: a link between cancer genetics and chemotherapy. Cell 108:153-164

44. Lawlor MA, Alessi DR (2001) PKB/Akt: a key mediator of cell proliferation, survival and insulin responses? J Cell Sci 114: 2903-2910

45. Wrede CE, Dickson LM, Lingohr MK, Briaud I, Rhodes CJ (2002) Protein kinase B/Akt prevents fatty acid-induced apoptosis in pancreatic beta-cells (INS-1). J Biol Chem 277: 49676-49684

46. Buteau J, El Assaad W, Rhodes CJ, Rosenberg L, Joly E, Prentki M (2004) Glucagon-like peptide-1 prevents beta cell glucolipotoxicity. Diabetologia 47:806-815

47. Wang Q, Brubaker PL (2002) Glucagon-like peptide-1 treatment delays the onset of diabetes in 8 week-old $d b / d b$ mice. Diabetologia 45:1263-1273

48. Tuttle RL, Gill NS, Pugh W et al (2001) Regulation of pancreatic beta-cell growth and survival by the serine/threonine protein kinase Akt1/PKBalpha. Nat Med 7:1133-1137

49. Bakin AV, Tomlinson AK, Bhowmick NA, Moses HL, Arteaga CL (2000) Phosphatidylinositol 3-kinase function is required for transforming growth factor beta-mediated epithelial to mesenchymal transition and cell migration. J Biol Chem 275 : 36803-36810

50. Johnstone RW, Ruefli AA, Lowe SW (2002) Apoptosis: a link between cancer genetics and chemotherapy. Cell 108:153-164

51. Scott FL, Denault JB, Riedl SJ, Shin H, Renatus M, Salvesen GS (2005) XIAP inhibits caspase-3 and -7 using two binding sites: evolutionarily conserved mechanism of IAPs. EMBO J 24:645-55

52. Hu P, Han Z, Couvillon AD, Exton JH (2004) Critical role of endogenous Akt/IAPs and MEK1/ERK pathways in counteracting endoplasmic reticulum stress-induced cell death. J Biol Chem 279:49420-49429 